\title{
The Ethical Implications of Personal Health Monitoring
}

\author{
Brent Mittelstadt, Centre for Computing and Social Responsibility, De Montfort University, \\ Leicester, UK
}

Ben Fairweather, Centre for Computing and Social Responsibility, De Montfort University, Leicester, UK

Mark Shaw, Centre for Computing and Social Responsibility, De Montfort University, Leicester, UK

Neil McBride, Centre for Computing and Social Responsibility, De Montfort University, Leicester, UK

\begin{abstract}
Personal Health Monitoring (PHM) uses electronic devices which monitor and record health-related data outside a hospital, usually within the home. This paper examines the ethical issues raised by PHM. Eight themes describing the ethical implications of PHM are identified through a review of 68 academic articles concerning PHM. The identified themes include privacy, autonomy, obtrusiveness and visibility, stigma and identity, medicalisation, social isolation, delivery of care, and safety and technological need. The issues around each of these are discussed. The system / lifeworld perspective of Habermas is applied to develop an understanding of the role of PHMs as mediators of communication between the institutional and the domestic environment. Furthermore, links are established between the ethical issues to demonstrate that the ethics of PHM involves a complex network of ethical interactions. The paper extends the discussion of the critical effect PHMs have on the patient's identity and concludes that a holistic understanding of the ethical issues surrounding PHMs will help both researchers and practitioners in developing effective PHM implementations. ${ }^{l}$
\end{abstract}

Keywords: $\quad$ Ethics, Habermas, Lifeworld, Literature Review, Personal Health Monitoring, System, Telecare, Telehealth

\section{INTRODUCTION}

The conjunction of wireless computing, ubiquitous internet access and the miniaturisation of sensors has opened the door for technological applications in medicine which allow the remote monitoring of medical conditions and relevant physiological parameters. Such technologies, examples of which are given in Table 1, come under the heading of personal health monitoring (PHM).

PHM refers to any electronic device or system that monitors and records data about a health-related aspect of a person's life outside

DOI: $10.4018 /$ ijt.2014070104 


\section{Table 1. Personal health monitoring technology examples}

Blood pressure monitoring - A patient with hypertension can use a wrist watch style device which monitors their blood pressure (BP) on a 24/7 basis (Laurance, 2011; Milenkovic, Otto \& Jovanov, 2006). The monitor can create a log of fluctuations throughout the day, and can automatically alert the user to heightened BP. The data can be analysed alongside a log of the user's behaviour throughout the day, which may reveal the effects of particular activities, foods, medications and other factors on the user's BP. This information may be usable by medical professionals to create a personalised treatment or lifestyle plan for the user.

In-vivo blood monitoring - Patients with a wide variety of disorders detectable through blood tests can make use of an in-vivo system which monitors blood quality in real time (Gaul \& Ziefle, 2009; PositiveID, 2011; Pousaz, 2013). Possible uses include real-time blood glucose monitoring for diabetics, or early warning of heart attacks from the presence of indicator substances which appear in the blood immediately before an incident. The effect of medications could also be tracked in real-time, leading to more personalised health interventions.

Smart home monitoring - Homebound chronically ill and elderly persons can make use of smart home technologies, which can detect behaviour and health parameters through sensors installed in the home (Chan, Campo, Estève \& Fourniols, 2009). Sensors could detect sleep patterns, activity levels, falls, and emergencies and automatically alert family members or medical professionals when an emergency occurs, or a problematic health or behaviour pattern emerges. The effect of medications could also be tracked through behavioural data. Information gathered by smart home sensors could be used to evaluate the care needs of 'at-risk' patients, and keep a 'watchful eye' on them when human carers are unavailable, which supports ageing at home for longer than would be possible without such monitoring.

Wearable sensors - 'Smart clothes' capable of measuring heart rate, respiration, body temperature and other physiological parameters could aid athletes in training and physical competition (Lymberis \& Gatzoulis, 2006; Milenkovic, Otto \& Jovanov, 2006). Emergencies and physical limits could be detected with precision.

a hospital setting. To qualify as PHM a device must be capable of transferring data to a third party and be usable by a layperson outside a traditional medical environment such as a hospital. PHM is related to 'telehealth and telecare' (Kaplan \& Litewka, 2008) and 'assistive technologies' (Demiris \& Hensel, 2009; Tiwari, Warren, Day \& McDonald, 2010), and covers various technologies including 'ambient intelligence'(Kosta, Pitkänen, Niemelä \& Kaasinen, 2010), 'somatic surveillance'(Monahan \& Wall, 2007),'wearable health sensors'(Arnrich, Mayora, Bardram \& Tröster, 2010; Lymberis $\&$ Gatzoulis, 2006) and medical 'surveillance technologies'(Niemeijer, Frederiks, Riphagen, Legemaate, Eefsting \& Hertogh, 2010).

The applications of PHM are wide, and can include physiological monitoring in healthy people, for example, for monitoring the body's response to sports activities (Ganti, Srinivasan \& Gacic, 2010; Monahan \& Wall, 2007). The primary focus of PHMs, which will be pursued in this paper, lies in the support of patients with long term chronic conditions such as chronic pulmonary obstructive disease, diabetes, asthma and heart disease (e.g. De Toledo, Jimenez, del Pozo, Roca, Alonso \& Hernandez, 2006; PositiveID, 2011; Ure, Pinnock, Hanley, Kidd, McCall Smith, Tarling et al., 2012). Such conditions often require long stays in hospital or hospitalisation at short notice. The use of PHMs may help patients to stay at home and live a more normal life outside the restrictions of institutionalisation (Empirica \& WRC, 2010; Remmers, 2010; van Hoof, Kort, Rutten \& Duijnstee, 2011). PHMs may also appear attractive to hospitals looking to reduce costs and free up hospital beds (e.g. Henderson, Knapp, Fernandez, J.-Beecham, Hirani, Cartwright et al., 2013; Lomas, 2009).

However, moving patients to their homes and implementing PHMs to enable monitoring by the hospital or clinicians changes the dynamic of the relationship between the patient and the hospital/clinicians, embedding aspects of medical institutions into the patient's home environment (e.g. Palm, Nordgren, Verweij \& Collste, 2012). Interventions may be done remotely and large amounts of medical data may be transferred from the home to the hospital or 
clinician. This may result in what Habermas (1992) terms the 'colonisation of the lifeworld' in which the private concerns and activities of the patient become the concerns of the public institution which draws information from the patient's private world and seeks to influence and change activities within the patient's home environment.

This dynamic connection between the hospital and the home changes the ethical climate (Huff, Barnard \& Frey, 2008) and requires addressing a variety of ethical issues. It creates a requirement for a new framework to address the social and ethical effects of PHM implementation. A first step towards such a framework will involve the identification of the ethical issues associated with PHM, which may subsequently lead to new tools for the evaluation of the social and ethical effects of PHMs in the field.

Three approaches to identifying the ethical issues may be considered. Firstly, the technology can be examined, characterised and analysed. This is the approach of the EUFP7 PHM-Ethics project (grant agreement no.: 230602) which sought to classify technologies and draw ethical issues from that classification (PHM Ethics Consortium, 2012). A second approach is to conduct fieldwork and question patients, carers and their clinicians. This approach is the focus of a current study (Mittelstadt, report currently in preparation for publication). A third approach involves examining applications through practitioner and researcher literature to see what ethical issues have been raised.

This paper reports the results of such a literature search which examined 339 articles with the aim of uncovering practitioner and researcher ethical concerns and presenting them in an ordered classification. The outcomes of the literature search and classification are then used as a basis for developing an understanding of the role of PHM as a mediator in the patient/ doctor relationship through a network of interlinked ethical factors which have a significant effect on the patient's identity as perceived by the patient and viewed by carers and healthcare professionals.
The next section describes the methodology by which ethical issues were derived from literature discussing PHM. The results of the analysis are then presented, and eight issues documented. The final section develops three perspectives based on the output of the literature review. The role of PHM is considered through the Habermasian lens of lifeworld and system. The ethical themes revealed from the literature study influence the delicate balance between lifeworld and system. In practical terms, the interpretation of ethical themes and the relationship between them is explored through the development of a cognitive map which helps identify the key foci to be considered in understanding the ethical impact of PHM and highlights the importance of interaction and links between ethical themes. The importance of identity as a key point of influence of PHM is discussed. Finally it is concluded that the clinical potential of PHM may be undermined if social and ethical issues are inadequately addressed, meaning the balance between the domestic practice within which the PHM resides and institutional demands may be disturbed.

The ethics of PHM requires a joining of medical ethics concerns with those of the ethics of ICT. This paper deals with the ethical and social aspects of the embedding of PHMs in the home and everyday lives of patients. It also conjoins philosophy and technology through the application of concepts and theories derived from the work of Habermas 1985). PHM is a technology which is shaped by society and whose acceptability is driven by the relationship between the individual and the institution. This is a significant concern of technoethics which encompasses all aspects of technology within a society shaped by technology (Luppicini, 2008). This paper not only seeks to combine applied ethics with the philosophy of technology and hence sits within the technoethics discipline; it also looks at an example of ordinary technoethics (Puech, 2013) as presently available and practiced within medicine and homes.

This paper raises a number of novel issues. It is of value to researchers in providing 
a comprehensive literature review and identifying a theoretical direction for future research. Furthermore it offers practitioners critical insights as to where effort should be directed in developing sensitive, ethical approaches to the use of PHM in clinical interventions.

\section{METHODS}

Academic literature available in four databases (Scopus, IEEE, MEDLINE, and CINAHL) addressing the ethical implications of PHM was reviewed between May 2010 and September 2012. A small selection of articles were also identified after this time period by hand searching of relevant journals identified in the database search. Attention was given to the discussion of ethical issues in each article, with the goal of identifying themes in the literature. The databases were searched to identify literature discussing ethical issues relating to the development and deployment of PHM. The search was limited to English language articles. Although most of the reviewed literature consists of peer-reviewed journal articles, other types of publications including commentaries, working reports, white papers and scientific books were included due to the exploratory nature of the review. Date restrictions were not placed on the search.

\section{Search Procedure}

Recognising that 'Personal Health Monitoring' is an emerging term not yet widely used in the literature, synonymous and related search terms were used including 'somatic surveillance', 'wearable body sensors', 'personalized health', 'pervasive health,' 'assistive technologies', 'ambient intelligence', 'health surveillance', 'ambient assisted living', and 'smart homes'. All articles matching the synonymous terminology were checked to ensure the technology under discussion matched the working definition of PHM.

Privacy, risk and security were excluded from the search queries because of the vast amount of literature written on these topics. To ensure the current discussion is comprehensive enough to allow for meaningful conclusions while still remaining a manageable size, and to give due attention to the uniqueness of privacy, risk and security as normative concepts, literature on these topics has been reviewed elsewhere (see: Mittelstadt, Fairweather, McBride \& Shaw, 2013). A future area for research may be to incorporate literature discussing privacy, risk and security aspects of PHM into the cognitive map developed here.

\section{Data Analysis}

Articles were reviewed to determine relevance to the current discussion, and were excluded if they only discussed development, implementation or technical specifications of PHM technologies. All articles were reviewed to identify treatment of the ethical effects of PHM in a process similar to conventional content analysis (Hsieh \& Shannon, 2005). Analysis identified key phrases and sentences which were interpreted and combined into themes present across multiple articles. To start, phrases and passages were highlighted that appeared to refer to ethical issues or concepts, understood as areas of 'right' and 'wrong' or the clash of competing normative interests among stakeholders. Highlighted segments were then coded to reflect the author's interpretation of the text (cf. Gadamer, 2004; Patterson \& Williams, 2002). Similar codes were then grouped and assigned to ethical themes. The frequency with which themes appeared in the literature is detailed in Table 4. This frequency was used as a guide to the discussion of results.

\section{Linkage between Ethical Themes}

The text output from the literature review was used as input to a cognitive mapping exercise. Cognitive mapping is a qualitative technique used to identify cause and effect and establish causal links (Eden, 1991; Eden and Ackerman, 1998). In this study, ethical concepts were identified and text examined to identify phrases that indicated linkage and that one ethical concept affected another. The search for links enabled the researchers to create an interpretation of the 
data which led to a more holistic understanding of how the ethical issues interacted.

\section{RESULTS}

A total of 341 articles were identified for review, 68 of which met the inclusion criteria of explicitly discussing ethical issues of PHM. Two sub-categories of PHM were identified during review of the literature, which are shown in Table 2. Five demographic groups of target users were also identified and presented in Table 3.

Through content analysis eight ethical themes emerged from the literature, which are reviewed in Table 4. Interpretation of findings and the designation of themes were discussed and agreed upon by the authors. The following is a thematic overview of the findings. Although the ethical themes emerged according to frequency, the overview does not merely highlight this frequency. Rather, the results discussed in the following sections were chosen for one of four reasons: (1) to draw attention to common interpretations of ethical themes and concepts, (2) to emphasise individual cases and issues that reveal unique ethical aspects of PHM, (3) to highlight studies with an in-depth analysis of ethical concepts and issues, and (4) to identify gaps in the discussion in need of further research. The presentation of results therefore focuses on the authors' analysis and interpretation of the literature.

\section{Table 2. Categories of PHM}

\begin{tabular}{|c|c|c|}
\hline Category of PHM & Description & References \\
\hline Mobile Monitors $(\mathrm{n}=26)$ & $\begin{array}{l}\text { Devices and } \\
\text { sensors carried, } \\
\text { worn by, or } \\
\text { implanted in the } \\
\text { user. }\end{array}$ & $\begin{array}{l}\text { Agrafioti, Bui \& Hatzinakos, 2011; Brey, 2005; De Bleser, De Geest, Vincke, Ruppar, } \\
\text { Vanhaecke \& Dobbels, 2011; Demiris, Doorenbos \& Towle, 2009; Dorsten, Sifford, } \\
\text { Bharucha, Mecca \& Wactlar, 2009; Fellbaum, 2008; Friedewald, Vildjiounaite, Punie } \\
\text { \& Wright, 2007; Gammon, Christiansen \& Wynn, 2009; Gaul \& Ziefle, 2009; Kosta, } \\
\text { Pitkänen, Niemelä \& Kaasinen, 2010; Kovach, Aubrecht, Dew, Myers \& Dabbs, 2011; } \\
\text { Landau, Auslander, Werner, Shoval \& Heinik, 2010; Landau, Werner, Auslander, Shoval } \\
\text { \& Heinik, 2010; Lauriks, Reinersmann, Van der Roest, Meiland, Davies, Moelaert et } \\
\text { al. 2007; Melander-Wikman, Jansson, Hallberg, Mörtberg \& Gard, 2007; Mittelstadt, } \\
\text { Fairweather, McBride \& Shaw, 2011; Monahan \& Wall, 2007; A. Nordgren, 2012; } \\
\text { Anders Nordgren, 2013; Palm, Nordgren, Verweij \& Collste, 2012; Pentland, 2009; } \\
\text { Rigby, 2007; Robinson, Hutchings, Corner, Finch, Hughes, Brittain \& Bond, 2007; } \\
\text { Welsh, Hassiotis, O’Mahoney \& Deahl, 2003; Ziefle \& Röcker, 2010, } 2010\end{array}$ \\
\hline $\begin{array}{l}\text { Environmental Monitors } \\
(\mathrm{n}=45)\end{array}$ & $\begin{array}{l}\text { Devices and } \\
\text { sensors embedded } \\
\text { in an environment, } \\
\text { such as a home, } \\
\text { vehicle, or } \\
\text { workplace, or a } \\
\text { stationary medical } \\
\text { appliance. }\end{array}$ & $\begin{array}{l}\text { Agree, Freedman, Cornman, Wolf \& Marcotte, 2005; Bowes, Dawson \& Bell, 2012; } \\
\text { Brey, 2005; Chan, Estève, Escriba \& Campo, 2008; Coughlin, D’Ambrosio, Reimer \& } \\
\text { Pratt, 2007; Courtney, Demiris \& Hensel, 2007; Courtney, 2008; Courtney, Demiris, } \\
\text { Rantz \& Skubic, 2008; Demiris \& Hensel, 2009; Demiris, 2009; Demiris, Rantz, Aud, } \\
\text { Marek, Tyrer, Skubic \& Hussam, 2004; Demiris, Oliver, Dickey, Skubic \& Rantz, 2008; } \\
\text { Ding, Cooper, Pasquina \& Fici-Pasquina, 2011; Dorsten, Sifford, Bharucha, Mecca } \\
\text { \& Wactlar, 2009; Essén, 2008; Fellbaum, 2008; Friedewald, Vildjiounaite, Punie \& } \\
\text { Wright, 2007; Fugger, Prazak, Hanke \& Wassertheurer, 2007; Gentry, 2009; Kenner, } \\
\text { 2008; Lauriks, Reinersmann, Van der Roest, Meiland, Davies, Moelaert et al. 2007; } \\
\text { Lyon, 2001; Mahoney, Purtilo, Webbe, Alwan, Bharucha, Adlam et al., 2007; Martin, } \\
\text { Cunningham \& Nugent, 2007; McLean, 2011; Melenhorst, Fisk, Mynatt \& Rogers, } \\
\text { 2004; Mittelstadt, Fairweather, McBride \& Shaw, 2011; Neild, Heatley, Kalawsky } \\
\text { \& Bowman, 2004; Niemeijer, Frederiks, Riphagen, Legemaate, Eefsting \& Hertogh, } \\
\text { 2010, 2010, 2011; A. Nordgren, 2012; Anders Nordgren, 2013; Palm, Nordgren, } \\
\text { Verweij \& Collste, 2012; Palm, 2011; Remmers, 2010; Rigby, 2007; Sadri, 2011; Stowe } \\
\text { \& Harding, 2010; Tiwari, Warren, Day \& McDonald, 2010; Townsend, Knoefel \& } \\
\text { Goubran, 2011; van Hoof, Kort, Markopoulos \& Soede, 2007; van Hoof, Kort, Rutten } \\
\text { \& Duijnstee, 2011; Vuokko, 2008; Welsh, Hassiotis, O’Mahoney \& Deahl, 2003; Wu, } \\
\text { Fassert \& Rigaud, 2012; Ziefle \& Röcker, 2010; Zwijsen, Niemeijer \& Hertogh, 2011 }\end{array}$ \\
\hline
\end{tabular}


Table 3. Demographics of target users

\begin{tabular}{|c|c|c|}
\hline \multicolumn{2}{|c|}{ Demographic } & \multirow[b]{2}{*}{$\begin{array}{l}\text { References } \\
\text { Agree, Freedman, Cornman, Wolf \& Marcotte, 2005; Bowes, Dawson \& Bell, 2012; } \\
\text { Chan, Estève, Escriba \& Campo, 2008; Coughlin, D'Ambrosio, Reimer \& Pratt, } \\
\text { 2007; Courtney, Demiris \& Hensel, 2007, 2008; Courtney, 2008; Demiris \& Hensel, } \\
\text { 2009; Demiris, Rantz, Aud, Marek, Tyrer, Skubic \& Hussam, 2004, 2009, 2008; } \\
\text { Demiris, 2009; Ding, Cooper, Pasquina \& Fici-Pasquina, 2011; Dorsten, Sifford, } \\
\text { Bharucha, Mecca \& Wactlar, 2009; Essén, 2008; Fellbaum, 2008; Friedewald, } \\
\text { Vildjiounaite, Punie \& Wright, 2007; Fugger, Prazak, Hanke \& Wassertheurer, 2007; } \\
\text { Gaul \& Ziefle, 2009; Gentry, 2009; Hensel, Demiris \& Courtney, 2006; Kenner, 2008; } \\
\text { Landau, Auslander, Werner, Shoval \& Heinik, 2010; Landau, Werner, Auslander, } \\
\text { Shoval \& Heinik, 2010; Lauriks, Reinersmann, Van der Roest, Meiland, Davies, } \\
\text { Moelaert et al. 2007; Mahoney, Purtilo, Webbe, Alwan, Bharucha, Adlam et al., } \\
\text { 2007; Martin, Cunningham \& Nugent, 2007; McLean, 2011; Melander-Wikman, } \\
\text { Jansson, Hallberg, Mörtberg \& Gard, 2007; Melenhorst, Fisk, Mynatt \& Rogers, } \\
\text { 2004; Mittelstadt, Fairweather, McBride \& Shaw, 2011; Neild, Heatley, Kalawsky } \\
\text { \& Bowman, 2004; Niemeijer, Frederiks, Riphagen, Legemaate, Eefsting \& Hertogh, } \\
\text { 2010, 2011; A. Nordgren, 2012; Anders Nordgren, 2013; Palm, Nordgren, Verweij } \\
\text { \& Collste, 2012; Palm, 2011; Percival \& Hanson, 2006; Remmers, 2010; Robinson, } \\
\text { Hutchings, Corner, Finch, Hughes, Brittain \& Bond, 2007; Sadri, 2011; Steele, Lo, } \\
\text { Secombe \& Wong, 2009; Stowe \& Harding, 2010; Tiwari, Warren, Day \& McDonald, } \\
\text { 2010; Townsend, Knoefel \& Goubran, 2011; van Hoof, Kort, Markopoulos \& Soede, } \\
\text { 2007; van Hoof, Kort, Rutten \& Duijnstee, 2011; Welsh, Hassiotis, O’Mahoney } \\
\text { \& Deahl, 2003; Wu, Fassert \& Rigaud, 2012; Ziefle \& Röcker, 2010; Zwijsen, } \\
\text { Niemeijer \& Hertogh, 2011 }\end{array}$} \\
\hline Elderly $(\mathrm{n}=52)$ & $\begin{array}{l}\text { Target audience } \\
\text { described as 'elderly' } \\
\text { or 'older'. }\end{array}$ & \\
\hline Ambiguous Age $(\mathrm{n}=12)$ & $\begin{array}{l}\text { Target audience age } \\
\text { not described. }\end{array}$ & $\begin{array}{l}\text { Agrafioti, Bui \& Hatzinakos, 2011; De Bleser, De Geest, Vincke, Ruppar, Vanhaecke } \\
\text { \& Dobbels, 2011; Fellbaum, 2008; Friedewald, Vildjiounaite, Punie \& Wright, 2007; } \\
\text { Kaplan \& Litewka, 2008; Kosta, Pitkänen, Niemelä \& Kaasinen, 2010; Mittelstadt, } \\
\text { Fairweather, McBride \& Shaw, 2011; Monahan \& Wall, 2007; Niemeijer, Frederiks, } \\
\text { Riphagen, Legemaate, Eefsting \& Hertogh, 2010; A. Nordgren, 2012; Palm, } \\
\text { Nordgren, Verweij \& Collste, 2012; Pentland, 2009 }\end{array}$ \\
\hline $\begin{array}{l}\text { Chronic Patients ( } \\
=18)\end{array}$ & $\begin{array}{l}\text { Target audience with a } \\
\text { chronic illness such as } \\
\text { dementia or diabetes } \\
\text { requiring long-term } \\
\text { care. }\end{array}$ & $\begin{array}{l}\text { Fellbaum, 2008; Friedewald, Vildjiounaite, Punie \& Wright, 2007; Gentry, 2009; } \\
\text { Kenner, 2008; Landau, Auslander, Werner, Shoval \& Heinik, 2010; Landau, Werner, } \\
\text { Auslander, Shoval \& Heinik, 2010; Lauriks, Reinersmann, Van der Roest, Meiland, } \\
\text { Davies, Moelaert et al. 2007; Mahoney, Purtilo, Webbe, Alwan, Bharucha, Adlam et } \\
\text { al., 2007; Martin, Cunningham \& Nugent, 2007; Mittelstadt, Fairweather, McBride \& } \\
\text { Shaw, 2011; Niemeijer, Frederiks, Depla, Legemaate, Eefsting \& Hertogh, 2011; A. } \\
\text { Nordgren, 2012; Anders Nordgren, 2013; Palm, Nordgren, Verweij \& Collste, 2012; } \\
\text { Robinson, Hutchings, Corner, Finch, Hughes, Brittain \& Bond, 2007; van Hoof, Kort, } \\
\text { Markopoulos \& Soede, 2007; Welsh, Hassiotis, O'Mahoney \& Deahl, } 2003\end{array}$ \\
\hline Acute Patients $(\mathrm{n}=12)$ & $\begin{array}{l}\text { Target audience } \\
\text { with an acute health } \\
\text { condition. }\end{array}$ & $\begin{array}{l}\text { Agrafioti, Bui \& Hatzinakos, 2011; De Bleser, De Geest, Vincke, Ruppar, Vanhaecke } \\
\text { \& Dobbels, 2011; Fellbaum, 2008; Friedewald, Vildjiounaite, Punie \& Wright, 2007; } \\
\text { Kosta, Pitkänen, Niemelä \& Kaasinen, 2010; Kovach, Aubrecht, Dew, Myers \& } \\
\text { Dabbs, 2011; Mittelstadt, Fairweather, McBride \& Shaw, 2011; Monahan \& Wall, } \\
\text { 2007; Niemeijer, Frederiks, Riphagen, Legemaate, Eefsting \& Hertogh, 2010; A. } \\
\text { Nordgren, 2012; Pentland, 2009; Rigby, } 2007\end{array}$ \\
\hline Healthy $(\mathrm{n}=3)$ & $\begin{array}{l}\text { Target audience not } \\
\text { described in terms of } \\
\text { health status, such as } \\
\text { in informational or } \\
\text { preventative PHM } \\
\text { applications (e.g. } \\
\text { lifestyle monitors). }\end{array}$ & $\begin{array}{l}\text { Monahan \& Wall, 2007; Niemeijer, Frederiks, Riphagen, Legemaate, Eefsting \& } \\
\text { Hertogh, 2010; Pentland, } 2009\end{array}$ \\
\hline Other $(\mathrm{n}=1)$ & $\begin{array}{l}\text { Field agents, e.g. } \\
\text { military. }\end{array}$ & Agrafioti, Bui \& Hatzinakos, 2011 \\
\hline
\end{tabular}

\section{Privacy}

Despite exclusion from the search query, privacy was frequently discussed in the reviewed literature. In line with results reported elsewhere
(Mittelstadt, Fairweather, McBride \& Shaw, 2013), the discussion of privacy in the literature reviewed here mostly affirmed a separation of data and personal privacy, and viewed security as privacy-enabling. ${ }^{2}$ 
Table 4. Ethical themes

\begin{tabular}{|c|c|c|}
\hline Theme & Central Issues and Concepts & References \\
\hline Autonomy $(\mathrm{n}=31)$ & $\begin{array}{l}\text { Rights to freedom, } \\
\text { independence, personal } \\
\text { decisions, technological } \\
\text { dependence }\end{array}$ & $\begin{array}{l}\text { Bowes, Dawson \& Bell, 2012; Brey, 2005; Demiris \& Hensel, 2009; } \\
\text { Demiris, 2009; Dorsten, Sifford, Bharucha, Mecca \& Wactlar, 2009; } \\
\text { Essén, 2008; Friedewald, Vildjiounaite, Punie \& Wright, 2007; Fugger, } \\
\text { Prazak, Hanke \& Wassertheurer, 2007; Gaul \& Ziefle, 2009; Gentry, 2009; } \\
\text { Kenner, 2008; Kosta, Pitkänen, Niemelä \& Kaasinen, 2010; Landau, } \\
\text { Auslander, Werner, Shoval \& Heinik, 2010; Landau, Werner, Auslander, } \\
\text { Shoval \& Heinik, 2010; Martin, Cunningham \& Nugent, 2007; Mittelstadt, } \\
\text { Fairweather, McBride \& Shaw, 2011; Monahan \& Wall, 2007; Niemeijer, } \\
\text { Frederiks, Riphagen, Legemaate, Eefsting \& Hertogh, 2010, 2011; Anders } \\
\text { Nordgren, 2013; Percival \& Hanson, 2006; Remmers, 2010; Rigby, 2007; } \\
\text { Robinson, Hutchings, Corner, Finch, Hughes, Brittain \& Bond, 2007; Steele, } \\
\text { Lo, Secombe \& Wong, 2009; Stowe \& Harding, 2010; Tiwari, Warren, Day } \\
\text { \& McDonald, 2010; Townsend, Knoefel \& Goubran, 2011; van Hoof, Kort, } \\
\text { Markopoulos \& Soede, 2007; Welsh, Hassiotis, O’Mahoney \& Deahl, 2003; } \\
\text { Zwijsen, Niemeijer \& Hertogh, 2011 }\end{array}$ \\
\hline $\begin{array}{l}\text { Stigma \& Identity ( } \mathrm{n} \\
=17 \text { ) }\end{array}$ & $\begin{array}{l}\text { Public/private stigma, self- } \\
\text { esteem, group identification, } \\
\text { aesthetics, community } \\
\text { implementation, risk-taking, } \\
\text { behavioural expectations, } \\
\text { passive control }\end{array}$ & $\begin{array}{l}\text { Bowes, Dawson \& Bell, 2012; Coughlin, D'Ambrosio, Reimer \& Pratt, } \\
\text { 2007; Courtney, 2008; Ding, Cooper, Pasquina \& Fici-Pasquina, 2011; Essén, } \\
\text { 2008; Gaul \& Ziefle, 2009; McLean, 2011; Mittelstadt, Fairweather, McBride } \\
\text { \& Shaw, 2011; Niemeijer, Frederiks, Riphagen, Legemaate, Eefsting } \\
\text { \& Hertogh, 2010; Anders Nordgren, 2013; Percival \& Hanson, 2006; } \\
\text { Remmers, 2010; Steele, Lo, Secombe \& Wong, 2009; Tiwari, Warren, Day \& } \\
\text { McDonald, 2010; van Hoof, Kort, Rutten \& Duijnstee, 2011; Wu, Fassert \& } \\
\text { Rigaud, 2012; Zwijsen, Niemeijer \& Hertogh, } 2011\end{array}$ \\
\hline Social Isolation $(\mathrm{n}=21)$ & $\begin{array}{l}\text { Replacement of human care, } \\
\text { supplementary care, lack } \\
\text { of social interaction, social } \\
\text { networking, informal carer } \\
\text { burdens }\end{array}$ & $\begin{array}{l}\text { Agree, Freedman, Cornman, Wolf \& Marcotte, 2005; Bowes, Dawson } \\
\text { \& Bell, 2012; Chan, Estève, Escriba \& Campo, 2008; Demiris, 2009; } \\
\text { Demiris, Rantz, Aud, Marek, Tyrer, Skubic \& Hussam, 2004; Friedewald, } \\
\text { Vildjiounaite, Punie \& Wright, 2007; Gentry, 2009; Kaplan \& Litewka, 2008; } \\
\text { McLean, 2011; Mittelstadt, Fairweather, McBride \& Shaw, 2011; Niemeijer, } \\
\text { Frederiks, Riphagen, Legemaate, Eefsting \& Hertogh, 2010; A. Nordgren, } \\
\text { 2012; Palm, 2011; Pentland, 2009; Percival \& Hanson, 2006; Sadri, 2011; } \\
\text { Stowe \& Harding, 2010; Tiwari, Warren, Day \& McDonald, 2010; van Hoof, } \\
\text { Kort, Rutten \& Duijnstee, 2011; Wu, Fassert \& Rigaud, 2012; Zwijsen, } \\
\text { Niemeijer \& Hertogh, } 2011\end{array}$ \\
\hline
\end{tabular}


Table 4. Continued

\begin{tabular}{|c|c|c|}
\hline Theme & Central Issues and Concepts & References \\
\hline Delivery of Care $(\mathrm{n}=9)$ & $\begin{array}{l}\text { Care community surveillance, } \\
\text { carer-patient power } \\
\text { relationships, behaviour } \\
\text { monitoring, information } \\
\text { overload, job security, } \\
\text { workplace surveillance }\end{array}$ & $\begin{array}{l}\text { Kaplan \& Litewka, 2008; Kenner, 2008; Mittelstadt, Fairweather, McBride } \\
\text { \& Shaw, 2011; Monahan \& Wall, 2007; Niemeijer, Frederiks, Riphagen, } \\
\text { Legemaate, Eefsting \& Hertogh, 2010; Percival \& Hanson, 2006; Remmers, } \\
\text { 2010; Tiwari, Warren, Day \& McDonald, 2010; Vuokko, } 2008\end{array}$ \\
\hline $\begin{array}{l}\text { Safety \& Technological } \\
\text { Need }(\mathrm{n}=13)\end{array}$ & $\begin{array}{l}\text { Misdiagnosis, priority of carer } \\
\text { beliefs, internal vs. external } \\
\text { perceptions of need, developer } \\
\text { claims, PHM enhancing health } \\
\text { and well-being, }\end{array}$ & $\begin{array}{l}\text { Courtney, Demiris, Rantz \& Skubic, 2008; Courtney, 2008; Ding, Cooper, } \\
\text { Pasquina \& Fici-Pasquina, 2011; Dorsten, Sifford, Bharucha, Mecca \& } \\
\text { Wactlar, 2009; Gammon, Christiansen \& Wynn, 2009; Kaplan \& Litewka, } \\
\text { 2008; Landau, Auslander, Werner, Shoval \& Heinik, 2010; Landau, Werner, } \\
\text { Auslander, Shoval \& Heinik, 2010; Lauriks, Reinersmann, Van der Roest, } \\
\text { Meiland, Davies, Moelaert et al. 2007; Neild, Heatley, Kalawsky \& Bowman, } \\
\text { 2004; Niemeijer, Frederiks, Depla, Legemaate, Eefsting \& Hertogh, 2011; } \\
\text { Anders Nordgren, 2013; Tiwari, Warren, Day \& McDonald, } 2010\end{array}$ \\
\hline Medicalisation $(\mathrm{n}=11)$ & $\begin{array}{l}\text { Altered perceptions of home, } \\
\text { health obsession, overdiagnosis, } \\
\text { doctor-patient relationship }\end{array}$ & $\begin{array}{l}\text { Bowes, Dawson \& Bell, 2012; Chan, Estève, Escriba \& Campo, 2008; } \\
\text { Courtney, Demiris, Rantz \& Skubic, 2008; Demiris \& Hensel, 2009; Gentry, } \\
\text { 2009; Mittelstadt, Fairweather, McBride \& Shaw, 2011; Niemeijer, Frederiks, } \\
\text { Riphagen, Legemaate, Eefsting \& Hertogh, 2010; Anders Nordgren, 2013; } \\
\text { Palm, Nordgren, Verweij \& Collste, 2012; Zwijsen, Niemeijer \& Hertogh, } \\
2011\end{array}$ \\
\hline Other $(\mathrm{n}=22)$ & $\begin{array}{l}\text { Informed consent, data mining, } \\
\text { equity of access, social } \\
\text { surveillance, behavioural } \\
\text { monitoring, white lies }\end{array}$ & $\begin{array}{l}\text { Informed Consent: Bagüés, Zeidler, Valdivielso \& Matias, 2007; } \\
\text { Bowes, Dawson \& Bell, 2012; Chan, Campo, Estève \& Fourniols, 2009; } \\
\text { Demiris, Doorenbos \& Towle, 2009; Demiris \& Hensel, 2009; Gammon, } \\
\text { Christiansen \& Wynn, 2009; Kaplan \& Litewka, 2008; Kenner, 2008; Martin, } \\
\text { Cunningham \& Nugent, 2007; Mittelstadt, Fairweather, McBride \& Shaw, } \\
\text { 2011; Neild, Heatley, Kalawsky \& Bowman, 2004; Remmers, 2010; Stowe } \\
\text { \& Harding, 2010 } \\
\text { Data Mining: Bowes, Dawson \& Bell, 2012; Fellbaum, 2008; Pentland, } \\
\text { 2009; Remmers, 2010 } \\
\text { Equity of Access: Demiris, 2009; Kosta, Pitkänen, Niemelä \& Kaasinen, } \\
2010 \\
\text { Social Surveillance: Friedewald, Vildjiounaite, Punie \& Wright, 2007; } \\
\text { Mahoney, Purtilo, Webbe, Alwan, Bharucha, Adlam et al., 2007; Monahan \& } \\
\text { Fisher, 2010; Monahan \& Wall, 2007; Pentland, 2009; Remmers, 2010 } \\
\text { Behavioural Monitoring: Fellbaum, 2008 } \\
\text { White Lies: Fellbaum, 2008 }\end{array}$ \\
\hline
\end{tabular}

\section{Autonomy}

Although autonomy was mentioned in several studies as an important ethical consideration, it was rarely elaborated as a concept. We interpreted it to include the right to make personal decisions (Demiris, 2009), a right to freedom (Brey, 2005) or a right to independence (Remmers, 2010). As implied by our interpretation, autonomy was often discussed in terms of freedom and independence, particularly in reference to assistive technologies (Remmers, 2010; Robinson, Hutchings, Corner, Finch, Hughes, Brittain \& Bond, 2007; Zwijsen, Niemeijer \& Hertogh, 2011), smarthomes (Brey, 2005; Remmers, 2010; Townsend, Knoefel \& Goubran, 2011) and residential care facilities (Dorsten,
Sifford, Bharucha, Mecca \& Wactlar, 2009; Zwijsen, Niemeijer \& Hertogh, 2011). The maintenance of independence in making decisions was interpreted as an issue of autonomy (Percival \& Hanson, 2006; Remmers, 2010), especially in community care settings where opt-in/out systems may be necessary to maintain respect for the autonomy of individual residents.

Areliance on PHM among dependent users may also be viewed as an issue of autonomy and identity (or self-confidence) (Brey, 2005; Friedewald, Vildjiounaite, Punie \& Wright, 2007). PHM can help care for individuals, for instance by automatically alerting someone in emergencies or when behaviours fall outside normal parameters. By providing a 'watchful safety net' PHM can reduce feelings of self- 
determination among users by reducing the need for self-reliance (Percival \& Hanson, 2006; Remmers, 2010) - if there is a perception that a carer will be alerted if something goes wrong (Bowes, Dawson \& Bell, 2011; Demiris, 2009; Fugger, Prazak, Hanke \& Wassertheurer, 2007), the importance of self-reliance is reduced. Dependent users may also experience changes to their role in user-carer relationships (Palm, Nordgren, Verweij \& Collste, 2012)-Kenner (2008) suggests carers can make judgments and interventions based on PHM data which could potentially infringe upon the user's rights to privacy and autonomy.

\section{Obtrusiveness and Visibility}

Obtrusiveness was identified as relevant to the acceptance and long-term use of PHM (De Bleser, De Geest, Vincke, Ruppar, Vanhaecke \& Dobbels, 2011; Demiris \& Hensel, 2009; Demiris, 2009; Townsend, Knoefel \& Goubran, 2011). Several studies employed a common framework of obtrusiveness in interviews and focus groups with users of smart home 'assistive technologies' (Demiris \& Hensel, 2009; Hensel, Demiris \& Courtney, 2006; Tiwari, Warren, Day $\&$ McDonald, 2010). The framework defines obtrusiveness, according to 22 subcategories, as "a summary evaluation by a person based on characteristics or effects associated with the technology that are perceived as undesirable and physically and/or psychologically prominent" (Hensel, Demiris \& Courtney, 2006, p. 430), meaning it is judged by the individual within a specific context. Although obtrusiveness appeared frequently as a term in the reviewed literature, the studies using this framework were alone in having a clear definition. The definition alludes to the distinction between physical and mental (or psychological) obtrusiveness as seen in non-medical ambient intelligence applications (cf. Brey, 2005). According to these studies, a sense of obtrusiveness would lead participants to subvert the monitoring system in some way, for example by not stepping on pressure sensors (Courtney, Demiris \& Hensel, 2007).
The related concept of visibility appears to refer to the degree to which a PHM is noticeable to the user and other individuals, both at home and in public (Essén, 2008; Landau, Werner, Auslander, Shoval \& Heinik, 2010; Robinson, Hutchings, Corner, Finch, Hughes, Brittain \& Bond, 2007; van Hoof, Kort, Rutten \& Duijnstee, 2011). Visibility differs from obtrusiveness in its emphasis on the public as well as private sphere. Characteristics affecting visibility included ease of use, size and weight (Landau, Werner, Auslander, Shoval \& Heinik, 2010), which suggests a link to the notions of mental and physical obtrusiveness, respectively. An example of PHM achieving low visibility occurred in two studies (Essén, 2008; van Hoof, Kort, Rutten \& Duijnstee, 2011) in which the presence of PHM was forgotten following extended use.

The psychological disappearance of PHM can be problematic in two ways. While disappearance may initially promote acceptance of the technology and preserve the meaning of the home (Courtney, 2008), users with cognitive impairment may eventually forget entirely about the monitoring equipment. This type of 'covert' monitoring raises questions of consent (Bowes, Dawson \& Bell, 2012; Kenner, 2008), which was not recognised in all studies mentioning the phenomenon (e.g. van Hoof, Kort, Rutten \& Duijnstee, 2011). The issue of consent can extend to individuals entering the home of a monitored individual, which suggests the possibility of inadvertent monitoring (Neild, Heatley, Kalawsky \& Bowman, 2004), although radio frequency identification (RFID) tags have been proposed as a solution to differentiate between residents and guests (Neild, Heatley, Kalawsky \& Bowman, 2004).

\section{Stigma and Identity}

'Stigma and Identity' refers to the implications of PHM for users resulting from the complex relationship between autonomy, visibility, stigma and identity. The relationship must be approached from both public and private 
perspectives to reveal the source of stigma and effects on user identity.

From a public perspective, PHM that is visible to others can cause the user to experience stigma, influencing self-esteem and self-identification as a patient. Such an effect was reported in a focus group study of elderly individuals in residential care (Courtney, 2008) in which participants felt that using PHM could lead to a feeling of frailty based on the public visibility of the devices. Residents were afraid that they would be judged for using PHM by other residents that did not need the devices, although it was suggested that the problem could be solved through aesthetic choices (Wu, Fassert \& Rigaud, 2012) or community wide implementation(Courtney, 2008). Attractive as the latter solution may be, it violates the principle that PHM solutions should be deployed to fit the individualised needs of the user to avoid 'monitoring for monitoring's sake' (Bowes, Dawson \& Bell, 2012), or pursuing monitoring as an end in itself (Coughlin, D'Ambrosio, Reimer \& Pratt, 2007; McLean, 2011).

From a private perspective, the relationship between autonomy and identity is important. Reliance on PHM raises questions about user identity, as PHM can affect the way a user perceives herself by fostering reliance on PHM for completion of daily tasks. This is especially true for elderly individuals wishing to retain independence and self-responsibility. By eliminating the opportunity to overcome obstacles associated with aging, PHM eliminates experiences that contribute to "a new sense [of] the meaning of life" for the elderly (Remmers, 2010, p. 203). If overcoming challenges is central to the creation of identity as a life progresses as Remmers (2010) asserts, then PHM which fosters reliance for completing daily tasks imposes profound limitations on the lives of elderly users. Even without technological reliance, systems can influence how a user's identity developers over time by automatically reporting risky or harmful behaviours indicative of frailty. These activities are often hidden by elders wishing to control the image presented to outsiders (Percival \&
Hanson, 2006), meaning PHM can erode the ability to manage public identity.

The public and private perspectives merge in considering expectations of behaviour. Users may feel pressure to behave in a certain way as a user of PHM, similar to the pressure placed on mentally or physically impaired individuals to conform to social expectations of behaviour (cf. Page-Hanify, 1980). This pressure is both public and private - for example, others may actually hold expectations of behaviour for impaired individuals, but even if such expectations do not exist the impaired person may self-impose behavioural limitations due to the perception that others hold such expectations. The same type of pressure can affect PHM users. If a device is (perceived as) publicly visible, the user may believe others harbour behavioural expectations; it matters not whether they actually exist, as the effect on the user is the same.

Even privately visible devices could lead to (perceived) expectations of behaviour among the user's family, friends and carers, as well as the user herself. Once a user has identified as (for example) 'frail' (Courtney, 2008), the expectations of behaviour need not be external: if a user believes a 'frail' individual to be someone that acts in a certain way, then the pressure to behave as such can be entirely internally imposed. Alternatively, users may believe the developers, administrators or the system itself harbour behavioural expectations. For example, smart homes have been shown to exhibit passive control over users, including the alteration of daily routines based on the presence of monitoring (Tiwari, Warren, Day \& McDonald, 2010). Such alterations have been traced to the perception of a "watcher" on the "other side" of the monitor (Essén, 2008,p. 134), or the perception that the monitoring system is expecting behaviours within a 'normal range'. This complex interaction between autonomy, visibility, stigma and identity may be dependent on a system's degree of obtrusiveness, although such an assumption would need to be empirically tested. 


\section{Social Isolation}

Concerns over social isolation were present in several studies based on the possibility that visits from medical personnel and carers may be less necessary if daily monitoring at home is achieved through PHM (Demiris, Rantz, Aud, Marek, Tyrer, Skubic \& Hussam, 2004; Stowe \& Harding, 2010; Tiwari, Warren, Day \& McDonald, 2010; Wu, Fassert \& Rigaud, 2012). This situation occurs if PHM is used to 'care' for patients in place of human carers, which can affect the frequency of visits and feelings of responsibility towards the patient. Studies involving older people have revealed a concern that PHM will replace personal and social interactions (Chan, Estève, Escriba \& Campo, 2008; McLean, 2011; Palm, 2011; Wu, Fassert \& Rigaud, 2012; Zwijsen, Niemeijer \& Hertogh, 2011) rather than supplementing them, while also reducing the amount of contextual information available when assessing a patient's condition (Percival \& Hanson, 2006), which suggests that the quality of diagnosis and care is diminished by the loss.

While a concern over increased social isolation was common, assistive homecare robots (Wu, Fassert \& Rigaud, 2012) and social networking features (Percival \& Hanson, 2006) have been proposed as solutions. Classifying these interventions as solutions rests on the questionable assumption that human interaction can be adequately replaced by technological interventions. According to Palm (2011, p. 9), if PHM is viewed by professional care providers as a replacement for social interaction among dependent patients, morally unjustifiable burdens may be placed on "informal carers" (family members, relatives, spouses) that are increasingly responsible for providing care and face-to-face interaction. Furthermore, although social networking can reduce feelings of isolation (Feenberg, Licht, Kane, Moran \& Smith, 1996), in doing so it forces users to give up personal information to regain the social interaction lost to PHM.

\section{Delivery of Care}

A small number of studies discussed the impact of PHM on medical personnel. Two studies examining caregivers and power relationships determined that 'surveillance' in a social care setting can lead to new power relationships among professional caregivers and recipients, thereby affecting the activities and interaction during caregiver visits (Kenner, 2008; Vuokko, 2008). For example, if given access to monitoring data caregivers can ensure their patients are following recommended medical interventions or detect risky behaviours, thereby disrespecting the patient's rights to privacy and selfdetermination(Remmers, 2010). Concerns were also expressed over the impact on professional caregivers, as PHM was alleged to threaten job security among home care workers based on a perception that it may be used as a tool of surveillance to expose human error, add to worker responsibilities (e.g. equipment maintenance) or complicate work routines (Tiwari, Warren, Day \& McDonald, 2010). Concerns were also raised that the influx of PHM data could cause "information overload" for nurses and physicians, who may be professionally obligated to review all available information about a patient (Kaplan \& Litewka, 2008, p. 403). These studies raise several important questions relating to the ethically acceptable level of workplace surveillance within the healthcare industry. Workers are clearly deserving of some level of privacy (cf. Lankshear \& Mason, 2001), yet this right may be necessarily eroded by the need to ensure the safety of patients.

\section{Safety and Technological Need}

Safety was described as an important factor in the decision to use PHM, and was often mentioned in connection with a 'need' for PHM. 'Safety' was interpreted as the detection and appropriate treatment of medical symptoms and behaviours. Several factors were identified as relevant to safety concerns among PHM 
users. One study identified a lack of contextual information in PHM data presented to physicians and nurses as a possible safety risk, potentially causing misdiagnosis (Kaplan \& Litewka, 2008). Despite this, systems are often promoted as protecting or enhancing the safety of users (Nordgren, 2012), particularly among individuals with dementia and their caregivers (Lauriks, Reinersmann, Van der Roest, Meiland, Davies, Moelaert et al. 2007). Safety appeared as a 'goal' that trumped concerns related to the other seven themes, particularly in studies of dementia caregiver attitudes, who often emphasise safety and peace of mind over other values, particularly privacy and autonomy (Landau, Werner, Auslander, Shoval \& Heinik, 2010; Topo, 2009). Caution should be exercised in employing safety as a trump card in the decision to use PHM, especially for persons lacking the capacity to consent. Systems claim to generically enhance the safety of users (Nordgren, 2012), which ignores the need for individuals with a variety of moral values and personal goals to interpret the meaning of 'safety' in specific contexts (Palm, Nordgren, Verweij \& Collste, 2012).

Despite the conceptual difficulties faced in the discussion of 'safety', it was frequently mentioned as the source of a 'need' for PHM among elderly and chronically ill individuals (Courtney, 2008; Melenhorst, Fisk, Mynatt \& Rogers, 2004). While the content of the 'need' for PHM was often taken for granted, one study (Courtney, Demiris, Rantz \& Skubic, 2008) explored perceptions of need in depth, describing it as multi-factored concept built upon internal and external perceptions of health and well-being, as well as the fit of the specific technology to the user's environment and current care regime.

\section{Medicalisation}

Medicalisation was rarely used as a term in the reviewed literature, although several studies described issues that can be interpreted as medicalisation of the home environment. In the context of the home, medicalisation occurs when a user is reminded of a health condition due to the presence of a monitoring system. In this sense, PHM introduces a medical aspect into the "experiences and meaning of home" (Courtney, 2008, p. 197), which is otherwise seen as place where privacy and identity are protected (Courtney, Demiris, Rantz \& Skubic, 2008). Multiple studies remind PHM developers of their responsibility in addressing the potential for medicalisation of the home (Bowes, Dawson \& Bell, 2012; Chan, Estève, Escriba \& Campo, 2008; Demiris \& Hensel, 2009; Gentry, 2009), which may affected co-inhabitants as well as the user, although this aspect of medicalisation was not addressed in the literature. Changes to the doctor-patient relationship caused by PHM (e.g. Palm, Nordgren, Verweij \& Collste, 2012) were also interpreted as an example of medicalisation. The term was also used to describe changes to the patient's identity caused by PHM, such as developing an obsession with health due to constant monitoring (Nordgren, 2013).

\section{DISCUSSION}

Although medicalisation was rarely mentioned in the reviewed literature, it provides a conceptual link to make sense of the variety of ethical effects of PHM. The lack of discussion of medicalisation in current literature does not necessarily undermine its potential as a 'keystone' for a framework to make sense of the ethical implications of PHM, particularly if medicalisation is conceived of as the sum of other ethical implications.

The argument made here is that many of the themes seen in the literature can be understood as contributing to a subtle medicalisation of the patient's 'lifeworld'. Specifically, introducing medical awareness into a patient's private physical and psychological spaces demonstrates how PHM embodies values and expectations beyond those of the user. Medicalisation hints at a broader conceptual framework, based on Habermas' notion of the system / lifeworld divide, to connect and 'make sense' of the various ethical implications of PHM. 


\section{The System/Lifeworld Perspective}

The use of PHM, in which data about a patient's condition is transmitted to a central point, provides benefits for both the hospital and the patient. The patient may gain peace of mind by knowing his safety is increased through constant monitoring, enabling advice on when an intervention is necessary and continuity in contact with clinical staff. As a result hospitals may be able to release beds, to work more efficiently and to reduce unnecessary admissions (cf. Henderson, Knapp, Fernandez, Beecham, Hirani, Cartwright et al., 2013). A delicate balance must be struck between two separate elements which Habermas characterises as the lifeworld and the system (Habermas, 1984, 1985). The ethical themes addressed in this paper: privacy, autonomy, obtrusiveness \& visibility, stigma \& identity, social isolation, care delivery and safety are all influenced by the nature of the lifeworld/system relationship, which lies at the centre of understanding how PHM acts as a conduit of medicalisation.

The lifeworld of the patient concerns the personal domain of the user of PHM, or the values, traditions, culture, accepted ways of behaving and being which are developed within families and cultures and expressed within the home and through cultural and social norms (Edgar, 2002; Habermas, 1984, 1985). A person's lifeworld is lived-out within personal environments and connected communities. The goal is one of belonging and safety within a living space. The lifeworld is concerned with quality of life and qualitative communication (Habermas, 1984, Chapter 6), and is formed and maintained through social communication in which relationships with communities are established (Edgar, 2002), often with an emphasis on the private and the hidden. The lifeworld may be expressed in the home in terms of layout, the arrangement of objects, and the meanings given to the space relating to identity, safety and privacy (cf. Williams, 2002).

In contrast, the system is not concerned with the personal, the private and the informal, but rather is concerned with the domain of institu- tions, power and economic goals (Habermas, 1975). It is concerned with the public sphere and the control of resources. The system discourse concerns concepts such as cost benefit analysis and quantitative communication. The system requires predictability and control hence there may be more of an emphasis on rules, structure and organisation. The system can be said to exist wherever it is understood that some actors in communication will pursue strategic action, often for shared purposes or mutual benefit (Habermas, 1984, Chapter 6): medical practice, in which communication is structured in a certain way to facilitate clinicians receiving required information from patients in an efficient manner (Barry, Stevenson, Britten, Barber \& Bradley, 2001), is one such example of how the system can influence communication.

The colonisation of the lifeworld occurs when the system seeks to exert its influence on the lifeworld and impinge controls and monitors (Habermas, 1984, 1985). Examples of colonisation include when the use of computer games at home becomes a leisure industry measured through cookies on the home computer and delivering personalised advertisements into the home (Truong, McColl \& Kitchen, 2010); or when government seek to promote personal computer usage in the home, persuade people to have them and survey levels of usage; or when behaviour in the home concerning child discipline and smoking becomes a subject of legislation (Barnett, 2008). The colonisation of the lifeworld by the system is characterised by increasing quantitisation which may pit the concerns of social and personal life against those of the institution and legislation.

However, it is not just a case of the system invading the lifeworld like colonial masters entering a tribal society. The quantitative systems within the medical environment - processes, bookings, money, boards of directors are ultimately legitimised by the lifeworld (cf. Edgar, 2002; Habermas, 1975). In exploring the system/lifeworld relationship influence both ways should be considered, although the power balance may be in favour of the system's invasion of the lifeworld. 
Within this perspective the role of PHM can be described as the communicative mediator of discourse between the system and the lifeworld. It bridges the communicative space between the lifeworld experienced at home and the wider concerns of society enshrined in the system. PHM has the potential to enable the colonisation of the lifeworld as the home becomes an extension of the hospital and the concerns of the institution affect attitudes, values and behaviour in the home. PHM enables the quantitisation of health parameters and home activity such that the needs of the system become the concerns of the lifeworld at home.

PHM can provide for extension of a lifeworld and incorporation of aspects of the system into a lifeworld, for example through video links into the home. Hence PHM can increase personal communication, and develop safety, peace of mind and security such that the lifeworld is preserved and developed. However, PHM can also restrict the lifeworld, impinging the system's economic and power concerns on the individual lifeworld such that restrictions are placed or information demanded in order to maintain institutional structures. Hence PHM has the potential to act both as the repressive father, dictating behaviour and routine and demanding information for his own purposes, or the supportive mother offering both reassurance but also an environment which supports the autonomy of the patient.

Each of the ethical themes described above can be conceptualised within the system/lifeworld divide. PHM may compromise privacy because it provides the system with access to information about activities and behaviour within the patient's home, whether through monitoring through sensors in the home or through data entered by the patient into an Internet-connected interface as might be the case, for example, with COPD patients (Gale $\&$ Sultan, 2013). This data may potentially be misused and access to the data represents an invasion of privacy by the system. However, the mere use of the PHM may enable a patient to be based at home rather than in a hospital where privacy will be much more restricted.
While autonomy is increased by the release of the lifeworld from the confines of hospitalisation, PHM still allows the system to invade the lifeworld and exert control through the quantisation and regulation of behaviour in the personal environment. Rituals and routines in the home become the concern of the system, as they become visible. They also may become more controllable with the presence of the PHM as physiological and behavioural characteristics are parameterised and measured. These measures, when provided to the system may result in intervention which regulates the behaviour of the user according to strategies and protocols legitimised by the system. It is in this sense that PHM is a surveillance technology (cf. Lyon, 2003; Monahan \& Wall, 2007) — it allows for the evaluation of the user at a distance as a quantified set of measurements, 'decontextualised' from the socially embodied person they represent.

The visibility of the PHM may also affect the user's identity, as PHM use becomes part of who they are, and affect behavioural patterns derived from the lifeworld. Behavioural patterns must be adapted to meet the requirements of PHM, whether that is in routines of monitoring by recording and transmitting physiological and behaviour data, or by routine of intervention, where therapies are conducted in response to the output of the PHM. The interpretation of what the numbers generated by PHM mean is most likely to be a system interpretation based on accepted protocol, research and clinical practice (cf. Molewijk, Stiggelbout, Otten, Dupuis \& Kievit, 2003). The interpretation then affects the lifeworld in making judgements about both physiological state and personal behaviour as to whether it is 'good' or 'bad', 'normal' or 'abnormal', thus restricting the future opportunities of the user (cf. Lyon, 2003). Such judgements may be effectively ethical judgements, such that the system is imposing moral boundaries on the lifeworld.

While reducing the obtrusiveness of PHM might help minimise the effects on a user's identity and autonomy, expressed through behaviours, the system will still be affecting the lifeworld through remote evaluation, feedback 
and interventions. Those interventions are determined by the system, based on clinical information and accepted treatment protocols and on the needs of the system which may concern economic justification of service provision or funding (e.g. Froggatt, Hockley, Parker \& Brazil, 2011).

The way in which the PHM acts as a conduit between the lifeworld and the system may support medicalisation in which the power imbalance between system and lifeworld, particularly amplified by the patient's dependency on the medical system, results in an invasion of the lifeworld. Additionally, by connecting the system and the lifeworld, PHM may reduce isolation by legitimising contact with healthcare personnel and care workers (Gale and Sultan, 2013), or increase it by giving the impression that the PHM is 'caring for' the user in place of a human carer.

The interpretation of delivery of care through the lens of system/lifeworld raises further issues. System concerns for control, regulation and economic management may not only be exerted on the patient as the user of PHM, but also on the care giver. Economic demands to optimise the use of paid-for care may result not only in the reduction of contact hours but also in the management and control of care giver activities through the proxy of PHMs capable of showing how metrics change when the care-giver is present.

The PHM as a conduit between the system and the lifeworld also enables the colonisation of the lifeworld by the system's agenda for safety, which may be determined by regulations appropriate for institutions but restrictive in the context of the home environment, and by rhetoric concerning technological need which is determined more by the system's requirement for efficiency or revenue than the patient's clinical or personal needs.

PHM mediates communication between the patient and the institution. Critical discourse between the patient and the professional concerning the implementation of PHM, the interpretation of data and the behavioural and clinical interventions resulting from the PHM should result in greater understanding of how the patient's lifeworld can be supported and how the colonisation of that lifeworld by the system can be limited. Hence PHM is a subject for dialogue which will raise issues about care, independence, progression and treatment of a disease which extend beyond the technical confines of the PHM. In this way it may be that the learning and understanding that emerges from the implementation of the PHM is more important than the technology itself.

\section{Linkage between Ethical Themes}

The discussion above indicates that the themes elicited within this review do not constitute a catalogue of standalone concerns but are linked together in a network of interactions. Using the technique of cognitive mapping of the issues discovered around the themes, a composite cognitive map (Figure 1) has been constructed which links ethical themes.

The map illustrates the web of influences between the ethical issues raise by the literature. Particularly two phenomena can be identified. Firstly, cascades of link can be seen such that an ethical issue may have an effect further down the line, the link for which may not be obvious. For example, PHM reliance, which is influence by perceived safety need, may increase surveillance, which increases carer power and reduces patient autonomy. This type of study may enable researchers and practitioners to identify initial concerns, which through a cascade of ethical themes may exert undue influence on key ethical concerns. In the case of PHM, perceived safety need may eventually reduce autonomy and increase medicalisation. In practice, a proper evaluation of safety needs which makes a realistic assessment of actual risks, and considers the patient's needs above those of institution and carers, may reduce the perceived need for PHM and hence protect autonomy and privacy.

Second, certain ethical issues can be seen as dominant and the target of other ethical influences. Hence in this review, the map suggests that autonomy is the key ethical issue, and is 
Figure 1. Cognitive map of linkages between ethical themes

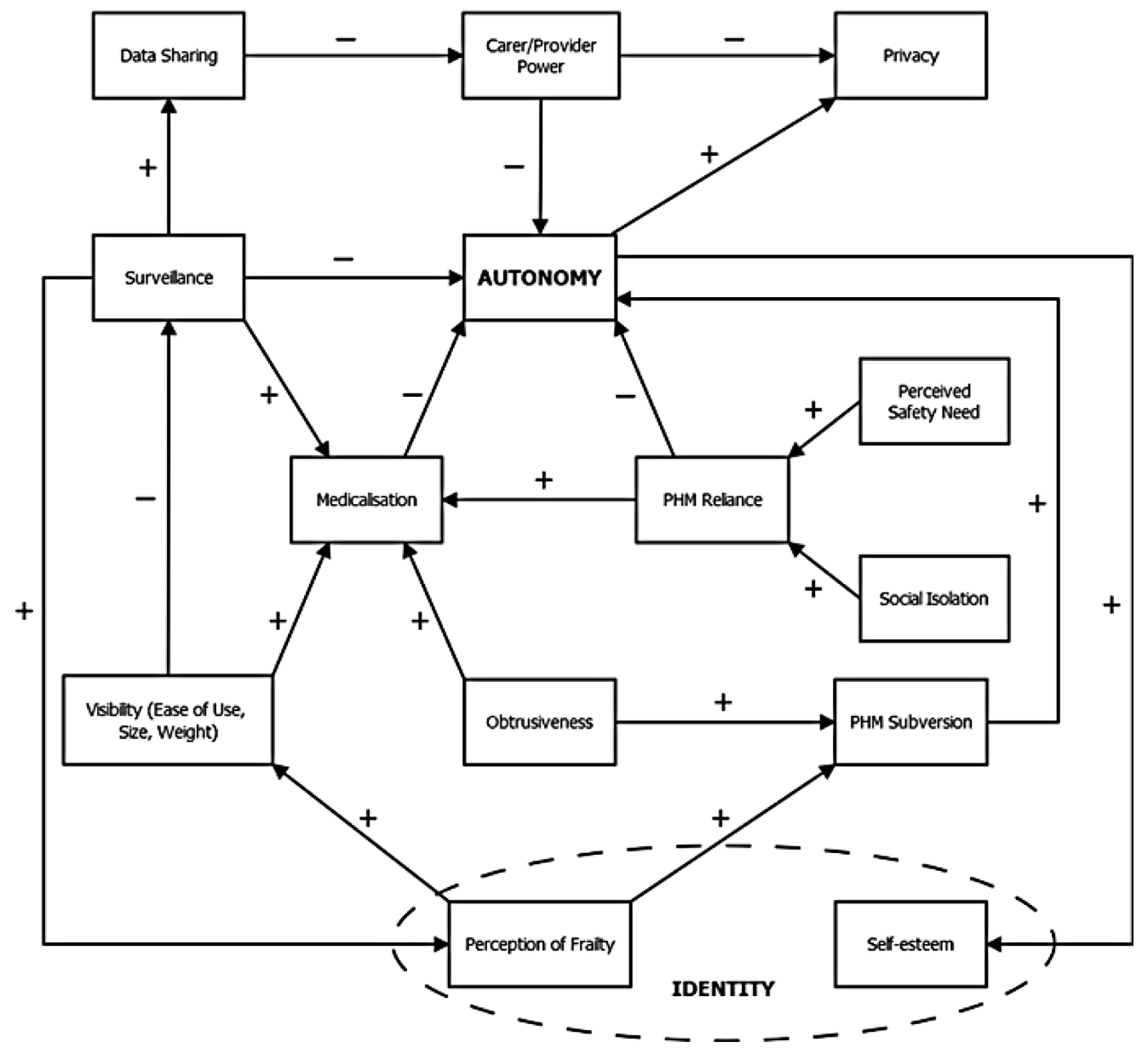

influenced by a range of other themes. Studies are therefore needed which examine the influence PHM has as a mediator in various medical relationships on the autonomy of the user or the subject, and the resulting implications for user autonomy of the system's colonising influence on the patient's lifeworld. With this said, privacy may also prove to be a key concept, as indicated by the quantity of results found in piloting this review which indicated the necessity of a separate review as indicated above. Its position in the framework as shown in Table 1 is meant to reflect this aspect of the review, meaning it may play a greater role in the ethics of PHM than acknowledged here.

It should be noted that for PHM, as for any technical intervention, it is context that matters and hence evaluation approaches should be developed which properly analyse the patient's situation in order to provide PHM interventions which are appropriate and beneficial. The study of networks also indicates that, besides concentration of influences in clusters around a particular node, single links to more distant aspects of the network may be critical in control. Here we note the link between autonomy 
and self-esteem, which itself is part of identity. We suggest that a critical ethical theme which needs development in the study of PHM ethics is that of identity, which is briefly addressed in the final section of this discussion.

\section{Identity}

Identity concerns a person's concept of who they are, the moral and social beliefs they embrace and how they relate to others. Identity works at a personal and social level; these influence each other (Fearon, 1999; Fearon and Latini, 2000). Biomedical advances such as PHM will affect people's identities (Foresight Future Identities, 2013). Attached to the person's body or installed in the personal environment, PHM becomes an extension of the person and an embodiment of the illness or the physical activity being monitored. A person's identity is often affected by an illness which becomes part of their identity, e.g. I'm a schizophrenic or I'm a COPD sufferer. The use of PHM may materialise the disease.

PHM will mediate relationships. Relationships such as husband, wife, father and mother are core parts of our identity. PHM may strengthen connections with health workers and hence those workers become part of a patient's identity through the mediation of the PHM. Furthermore, the connection with the institution provided by the PHM may influence identity. The patient may now see being a patient of a particular hospital as a part of his identity even while at home. The colonisation of the lifeworld by the system, mediated by the PHM may impose institutional identity on the patient's individual identity. Interaction of system and lifeworld could be seen as creating a third identity which amalgamates the institutional identity, that is the public and exposed identity, and the domestic identity, the hidden private identity.

Since PHM influences and materialises key aspects of the patient's identity - illness, metrics, institutional relationships - clinicians and researchers should pay particular attention to the influence of PHM on the user's identity and how changes in identity influence dependency and autonomy. Furthermore, the persistence of data generated by PHMs may make it more difficult to shake off a pathologically-based identity when PHM usage ceases, for example if the disease is cured.

\section{CONCLUSION}

The developing technology of personal health monitoring has great potential to support improvements in healthcare. Data generated has the potential, using the techniques of business intelligence to generate useful clinical insights which may progress medical care. But an uncritical focus on the technology may result in a failure to observe the social and ethical effects of PHM, ultimately undermining its clinical potential. Therefore attention must be paid to the ethical effects of PHMs if real value is to be obtained.

In this study a survey of literature has served as a vehicle for identifying potential ethical issues with PHM including privacy, autonomy, obtrusiveness, identity, social isolation, safety and medicalisation. However, the cataloguing of these ethical issues does not provide an adequate framework for sensitively managing the critical social and ethical effects of PHMs. Hence this paper progressed to developing key conceptual frameworks which will support researchers and practitioners alike in understanding PHM and deploying it in a clinically valuable manner.

The use of the system/lifeworld framework clearly highlights the sensitive role of PHM in personal and medical relationships. Rather than treating PHM as an isolated technical entity, with a focus on the ethics of the artefact, this study treats PHM as a communication conduit between the institutional life of the hospital and the domestic life of the patient, identified as the system and the lifeworld respectively. As such the PHM is not necessarily a technological source of ethical concerns. Rather it is a conduit for the flow of ethical concerns between the system and the lifeworld which inevitably alters the potency of such concerns and the ability of 
the user to manage them. Each of the ethical themes identified in the literature search may be interpreted in the context of the effects of PHM on the relationship between system and lifeworld. Additionally, this paper challenges the treatment of ethical issues in technology as standalone factors and through the analysis of the literature, identifies chains of cause and effect which generate complex networks of interacting ethical factors.

Finally, it cannot be escaped that health, illness, disability and treatments constitute a significant element of a person's identity and can become the predominant label patients associate with themselves. Even the use of crutches has a powerful effect on how the patient views her identity as well as the perception of observers, relatives and friends. How much more, then, will complex ICT, located in the home, determine patients' perceptions of themselves and carer's behaviour towards them, even if it is hidden on the body or embedded discretely in the domestic environment? For researchers, a holistic understanding of the ethical issues of PHM, coupled with an understanding of the differentiation between the institution and the domestic practices provides a rich opportunity for field studies which will contribute to a deeper understanding of the role of advanced technologies in mediating social relationships.

\section{REFERENCES}

Agrafioti, F., Bui, F. M., \& Hatzinakos, D. (2011). Medical biometrics in mobile health monitoring. Security and Communication Networks, 4(5), 525-539. doi: $10.1002 /$ sec. 227

Agree, E. M., Freedman, V. A., Cornman, J. C., Wolf, D. A., \& Marcotte, J. E. (2005). Reconsidering substitution in long-term care: When does assistive technology take the place of personal care? The Journals of Gerontology. Series B, Psychological Sciences and Social Sciences, 60(5), S272-S280. doi:10.1093/geronb/60.5.S272 PMID:16131628
Arnrich, B., Mayora, O., Bardram, J., \& Tröster, G. (2010). Pervasive healthcare paving the way for a pervasive, user-centered and preventive healthcare model. Methods of Information in Medicine, 49, 6773. doi: doi:10.3414/me09-02-0044PMID:20011810

Bagüés, S. A., Zeidler, A., Valdivielso, F., \& Matias, R. (2007). Disappearing for a while - Using white lies in pervasive computing. Proceedings of the 2007 ACM workshop on Privacy in electronic society, (pp. 80-83). Alexandria, VA. doi:10.1145/1314333.1314349

Barnett, L. (2008). The "Spanking" Law: Section 43 of the Criminal Code (PRB 05-10E). Law and Government Division, Parliament of Canada. Retrieved from http://www.parl.gc.ca/content/lop/ researchpublications/prb0510-e.htm

Barry, C. A., Stevenson, F. A., Britten, N., Barber, N., \& Bradley, C. P. (2001). Giving voice to the lifeworld. More humane, more effective medical care? A qualitative study of doctor-patient communication in general practice. Social Science \& Medicine, 53(4), 487-505. doi:10.1016/S0277-9536(00)00351-8 PMID:11459399

Bohn, J., Coroamă, V., Langheinrich, M., Mattern, F., \& Rohs, M. (2005). Social, economic, and ethical implications of ambient intelligence and ubiquitous computing. Institute for Pervasive Computing. Retrieved from http://citeseerx.ist.psu.edu/viewdoc/ summary?doi=10.1.1.70.2159

Bowes, A., Dawson, A., \& Bell, D. (2012). Ethical Implications of Lifestyle Monitoring Data in Ageing Research. Information Communication and Society, 15(1), 5-22. doi:10.1080/1369118X.2010.530673

Brey, P. (2005). Freedom and privacy in ambient intelligence. Ethics and Information Technology, 7(3), 157-166. doi:10.1007/s10676-006-0005-3

Chan, M., Campo, E., Estève, D., \& Fourniols, J. Y. (2009). Smart homes - Current features and future perspectives. Maturitas, 64(2), 90-97. doi:10.1016/j. maturitas.2009.07.014 PMID:19729255

Chan, M., Estève, D., Escriba, C., \& Campo, E. (2008). A review of smart homes - Present state and future challenges. Computer Methods and Programs in Biomedicine, 91(1), 55-81. doi:10.1016/j. cmpb.2008.02.001 PMID:18367286 
Coughlin, J. F., D’Ambrosio, L. A., Reimer, B., \& Pratt, M. R. (2007). OlderAdult Perceptions of Smart Home Technologies: Implications for Research, Policy \& Market Innovations in Healthcare. Proceedings of the 29th Annual International Conference of the IEEE Engineering in Medicine and Biology Society, 2007. EMBS 2007 (pp. 1810-1815). doi:10.1109/ IEMBS.2007.4352665

Courtney, K. L. (2008). Privacy and senior willingness to adopt smart home information technology in residential care facilities. Methods of Information in Medicine, 47, 76-81. doi: doi:10.3414/me9104 PMID:18213432

Courtney, K. L., Demiris, G., \& Hensel, B. K. (2007). Obtrusiveness of information-based assistive technologies as perceived by older adults in residential care facilities: A secondary analysis. Medical Informatics and the Internet in Medicine, 32(3), 241-249. doi:10.1080/14639230701447735 PMID:17701829

Courtney, K. L., Demiris, G., Rantz, M., \& Skubic, M. (2008). Needing smart home technologies: The perspectives of older adults in continuing care retirement communities. Informatics in Primary Care, 16 , 195-201. PMID:19094406

De Bleser, L., De Geest, S., Vincke, B., Ruppar, T., Vanhaecke, J., \& Dobbels, F. (2011). How to test electronic adherence monitoring devices for use in daily life: A conceptual framework. CIN -. Computers, Informatics, Nursing, 29(9), 489-495. doi:10.1097/ NCN.0b013e31821a1555 PMID:21532468

De Toledo, P., Jimenez, S., del Pozo, F., Roca, J., Alonso, A., \& Hernandez, C. (2006). Telemedicine Experience for Chronic Care in COPD. IEEE Transactions on Information Technology in Biomedicine, 10(3), 567-573. doi:10.1109/TITB.2005.863877 PMID:16871726

Demiris, G. (2009). Privacy and social implications of distinct sensing approaches to implementing smart homes for older adults. Conference proceedings: Annual International Conference of the IEEE Engineering in Medicine and Biology Society. (pp. 4311-4314). doi:10.1109/IEMBS.2009.5333800

Demiris, G., Doorenbos, A. Z., \& Towle, C. (2009). Ethical considerations regarding the use of technology for older adults. The case of telehealth. Research in Gerontological Nursing, 2(2), 128-136. doi:10.3928/19404921-20090401-02 PMID:20077974
Demiris, G., \& Hensel, B. K. (2009). "Smart homes" for patients at the end of life. Journal of Housing for the Elderly, 23(1-2), 106-115. doi:10.1080/02763890802665049

Demiris, G., Oliver, D. P., Dickey, G., Skubic, M., \& Rantz,M.(2008). Findings from a participatory evaluation of a smart home application for older adults. Technologyand Health Care, 16,111-118.PMID:18487857

Demiris, G., Rantz, M., Aud, M., Marek, K., Tyrer, H., Skubic, M., \& Hussam, A. (2004). Older adults' attitudes towards and perceptions of 'smart home' technologies: a pilot study. Informatics for Health and Social Care, 29, 87-94. doi:citeulike-articleid:6074761

Ding, D., Cooper, R. A., Pasquina, P. F., \& FiciPasquina, L. (2011). Sensor technology for smart homes. Maturitas, 69(2), 131-136. doi:10.1016/j. maturitas.2011.03.016 PMID:21531517

Dorsten, A. M., Sifford, S. K., Bharucha, A., Mecca, L. P., \& Wactlar, H. (2009). Ethical perspectives on emerging assistive technologies: Insights from focus groups with stakeholders in long-term care facilities. Journal of Empirical Research on Human Research Ethics; JERHRE, 4(1), 25-36. doi:10.1525/ jer.2009.4.1.25 PMID:19374478

Eden, C. (1988). Cognitive Mapping: A Review. European Journal of Operational Research, 36(1), 1-13. doi:10.1016/0377-2217(88)90002-1

Eden, C., \& Ackermann, F. C. (1998). Making Strategy: The Journey of Strategic Management. Sage Publications.

Edgar, A. (2002). Habermas: The Key Concepts. Routledge.

Empirica \& WRC. (2010). ICT \& Ageing-European Study on Users, Markets and Technologies: Final Report. European Commission. Retrieved from http:// www.ict-ageing.eu/ict-ageing-website/wp-content/ uploads/2010/D18_final_report.pdf

Essén, A. (2008). The two facets of electronic care surveillance: An exploration of the views of older people who live with monitoring devices. Social Science \& Medicine, 67(1), 128-136. doi:10.1016/j. socscimed.2008.03.005 PMID:18396367

Feenberg, A. L., Licht, J. M., Kane, K. P., Moran, K., \& Smith, R. A. (1996). The online patient meeting. Journal of the Neurological Sciences, 139, 129-131. doi:10.1016/0022-510X(96)00093-7PMID:8899672 
Fellbaum, K. (2008). The future: Communication in an ambient intelligence environment. Technology and Disability, 20, 157-171.

Foresight Future Identities. (2013). Final Project Report. London: The Government Office for Science.

Friedewald, M., Vildjiounaite, E., Punie, Y., \& Wright, D. (2007). Privacy, identity and security in ambient intelligence: A scenario analysis. Telematics and Informatics, 24(1), 15-29. doi:10.1016/j. tele.2005.12.005

Froggatt, K., Hockley, J., Parker, D., \& Brazil, K. (2011). A system lifeworld perspective on dying in long term care settings for older people: Contested states in contested places. Health \& Place, 17(1), 263-268. doi:10.1016/j.healthplace.2010.11.001 PMID:21146443

Fugger, E., Prazak, B., Hanke, S., \& Wassertheurer, S. (2007). Requirements and Ethical Issues for Sensor-Augmented Environments in Elderly Care. In C. Stephanidis (Ed.), Universal Acess in Human Computer Interaction. Coping with Diversity (pp. 887-893). Lecture Notes in Computer Science Berlin: Springer. doi:10.1007/978-3-540-73279-2_99

Gadamer, H. G. (2004). Truth and Method. Continuum International Publishing Group.

Gale, N., \& Sultan, H. (2013). Telehealth as "peace of mind": Embodiment, emotions and the home as the primary health space for people with chronic obstructive pulmonary disorder. Health \& Place, 21,140-147.doi:10.1016/j.healthplace.2013.01.006 PMID:23474353

Gammon, D., Christiansen, E. K., \& Wynn, R. (2009). Exploring morally relevant issues facing families in their decisions to monitor the health-related behaviours of loved ones. Journal of Medical Ethics, 35(7), 424-428. doi:10.1136/jme.2008.027920 PMID: 19567691

Ganti, R. K., Srinivasan, S., \& Gacic, A. (2010). Multisensor Fusion in Smartphones for Lifestyle Monitoring. Proceedings of the 2010 International Conference on Body Sensor Networks (BSN). (pp. 36 -43). doi:10.1109/BSN.2010.10

Gaul, S., \& Ziefle, M. (2009). Smart Home Technologies: Insights into Generation-Specific Acceptance Motives. In A. Holzinger, \& K. Miesenberger (Eds.), HCI and Usability for e-Inclusion (pp. 312-332). Lecture Notes in Computer Science Berlin: Springer. doi:10.1007/978-3-642-10308-7 22
Gentry, T. (2009). Smart homes for people with neurological disability: State of the art. NeuroRehabilitation, 25, 209-217. PMID:19893189

Habermas, J. (1975). Legitimation Crisis (T. McCarthy, Trans.). Boston: Beacon.

Habermas, J. (1984). The Theory of Communicative Action: Vol. 1. Reason and the Rationalization of Society. Boston: Beacon.

Habermas, J. (1985). The Theory of Communicative Action: Vol. 2. Lifeworld and System: A Critique of Functionalist Reason. Boston: Beacon.

Henderson, C., Knapp, M., Fernandez, J. L., Beecham, J., Hirani, S. P., \& Cartwright, M. et al. (2013). Cost effectiveness of telehealth for patients with long term conditions (Whole Systems Demonstrator telehealth questionnaire study): Nested economic evaluation in a pragmatic, cluster randomised controlled trial. BMJ (ClinicalResearch Ed.), 346,f1035-f1035. doi: doi:10.1136/bmj.f1035 PMID:23520339

Hensel, B. K., Demiris, G., \& Courtney, K. L. (2006). Defining Obtrusiveness in Home Telehealth Technologies: A Conceptual Framework. Journal of the American Medical Informatics Association, 13(4), 428-431. doi:10.1197/jamia.M2026 PMID:16622166

Hsieh, H. F., \& Shannon, S. E. (2005). Three Approaches to Qualitative Content Analysis. Qualitative Health Research, 15(9), 1277-1288. doi:10.1177/1049732305276687 PMID:16204405

Huff, C., Barnard, L., \& Frey, W. (2008). Good computing: A pedagogically focused model of virtue in the practice of computing (part 1). Journal of Information. Communication and Ethics in Society, 6(3), 246-278. doi:10.1108/14779960810916246

Kaplan, B., \& Litewka, S. (2008). Ethical Challenges of Telemedicine and Telehealth. Cambridge Quarterly of Healthcare Ethics, 17(04), 401-416. doi:10.1017/S0963180108080535 PMID:18724880

Kenner, A. M. (2008). Securing the Elderly Body: Dementia, Surveillance, and the Politics of "Aging in Place.”. Surveillance \& Society, 5, 252-269.

Kosta, E., Pitkänen, O., Niemelä, M., \& Kaasinen, E. (2010). Mobile-centric ambient intelligence in Health- and Homecare-anticipating ethical and legal challenges. Science and Engineering Ethics, 16(2), 303-323. doi:10.1007/s11948-009-9150-5 PMID:19597967 
Kovach, K. A., Aubrecht, J. A., Dew, M. A., Myers, B., \& Dabbs, A. D. (2011). Data safety and monitoring for research involving remote health monitoring. Telemedicine Journal and e-Health, 17(7), 574-579. doi:10.1089/tmj.2010.0219 PMID:21749259

Landau, R., Auslander, G. K., Werner, S., Shoval, N., \& Heinik, J. (2010). Families and professional caregivers views of using advanced technology to track people with dementia. Qualitative Health Research, 20(3), 409-419. doi:10.1177/1049732309359171 PMID:20133506

Landau, R., Werner, S., Auslander, G. K., Shoval, N., \& Heinik, J. (2010). What do cognitively intact older people think about the use of electronic tracking devices for people with dementia? A preliminary analysis. International Psychogeriatrics, 22(08), 1301-1309. doi:10.1017/S1041610210001316 PMID:20594387

Lankshear, G., \& Mason, D. (2001). Technology and ethical dilemmas in a medical setting: Privacy, professional autonomy, life and death. Ethics and Information Technology, 3(3), 223-233. doi:10.1023/A:1012248219018

Laurance, J. (2011). Revolutionary "wrist watch" to monitor high blood pressure. The Independent. London. Retrieved from http://www.independent. co.uk/life-style/health-and-families/health-news/ revolutionary-wrist-watch-to-monitor-high-bloodpressure-2220650.html

Lauriks, S., Reinersmann, A., Van der Roest, H. G., Meiland, F. J. M., Davies, R. J., \& Moelaert, F. et al. (2007). Review of ICT-based services for identified unmet needs in people with dementia. Ageing Research Reviews, 6(3), 223-246. doi:10.1016/j. arr.2007.07.002 PMID:17869590

Lomas, C. (2009). Telehealth system slashes hospital admissions in COPD patients. Retrieved from http:// www.nursingtimes.net/nursing-practice/clinicalzones/copd/telehealth-system-slashes-hospitaladmissions-in-copd-patients/5005885.article

Luppicini, R. (2009). The emerging field of technoethics. In R. Luppicini, \& R. Adell (Eds.), Handbook of research on technoethics (pp. 1-19). IGI Global.

Lymberis, A., \& Gatzoulis, L. (2006). Wearable Health Systems: from smart technologies to real applications. Proceedings of the Annual International Conference of the IEEE Engineering in Medicine and Biology Society (pp. 6789-6792). doi:10.1109/ IEMBS.2006.260948
Lyon, D. (2001). Facing the future: Seeking ethics for everyday surveillance. Ethics and Information Technology, 3(3), 171-180. doi:10.1023/A:1012227629496

Lyon, D. (2003). Surveillance as social sorting : privacy, risk, and digital discrimination. London: Routledge.

Mahoney, D. F., Purtilo, R. B., Webbe, F. M., Alwan, M., Bharucha, A. J., \& Adlam, T. D. et al. (2007). Inhome monitoring of persons with dementia: Ethical guidelines for technology research and development. Alzheimer's \& Dementia: The Journal of the Alzheimer's Association, 3(3), 217-226. doi:10.1016/j. jalz.2007.04.388 PMID:19595941

Martin, S., Cunningham, C., \& Nugent, C. (2007). Ethical Considerations for Integrating Technology. Alzheimer's Care Today, 8, 251-258. doi: doi:10.1097/01.ALCAT.0000281873.66023.7e

McLean, A. (2011). Ethical frontiers of ICT and older users: Cultural, pragmatic and ethical issues. Ethics and Information Technology, 13(4), 313-326. doi:10.1007/s10676-011-9276-4

Melander-Wikman, A., Jansson, M., Hallberg, J., Mörtberg, C., \& Gard, G. (2007). The Lighthouse Alarm and Locator trial - A pilot study. Technology and Health Care, 15, 203-212. PMID:17473400

Melenhorst, A.-S., Fisk, A. D., Mynatt, E. D., \& Rogers, W. A. (2004). Potential Intrusiveness of Aware Home Technology: Perceptions of Older Adults. Proceedings of the Human Factors and Ergonomics Society Annual Meeting (Vol. 48, pp. 266-270). doi:10.1177/154193120404800209

Milenkovic, A., Otto, C., \& Jovanov, E. (2006). Wireless sensor networks for personal health monitoring: Issues and an implementation. Computer Communications, 29(13-14), 2521-2533. doi:10.1016/j. comcom.2006.02.011

Mittelstadt, B., Fairweather, N. B., McBride, N., \& Shaw, M. (2011). Ethical Issues of Personal Health Monitoring: A Literature Review. ETHICOMP 2011 Conference Proceedings (pp. 313-321).

Mittelstadt, B., Fairweather, N. B., McBride, N., \& Shaw, M. (2013). Privacy, Risk and Personal Health Monitoring. ETHICOMP 2013 Conference Proceedings (pp. 340-351). 
Molewijk, A. C., Stiggelbout, A. M., Otten, W., Dupuis, H. M., \& Kievit, J. (2003). Implicit Normativity in Evidence-Based Medicine: A Plea for Integrated Empirical Ethics Research. Health Care Analysis, 11(1), 69-92. doi:10.1023/A:1025390030467 PMID: 14510310

Monahan, T., \& Fisher, J. A. (2010). Implanting Inequality: Empirical Evidence of Social and Ethical Risks of Implantable Radio-Frequency Identification (RFID) Devices. International Journal of Technology Assessment in Health Care, 26(4), 370-376. doi:10.1017/S0266462310001133 PMID:20923593

Monahan, T., \& Wall, T. (2007). Somatic surveillance: corporeal control through information networks. SSOAR - Social Science Open Access Repository. Retrieved from http://nbn-resolving.de/ urn:nbn:de:0168-ssoar-64160

Neild, I., Heatley, D. J. T., Kalawsky, R. S., \& Bowman, P.A. (2004). Sensor Networks for Continuous Health Monitoring. BT Technology Journal, 22(3), 130-139. doi:10.1023/B:BTTJ.0000047127.01462.49

Niemeijer, A. R., Frederiks, B. J., Riphagen, I. I., Legemaate, J., Eefsting, J. A., \& Hertogh, C. M. (2010). Ethical and practical concerns of surveillance technologies in residential care for people with dementia or intellectual disabilities: An overview of the literature. International Psychogeriatrics, 22(07), 1129-1142. doi:10.1017/S1041610210000037 PMID:20199699

Niemeijer, A. R., Frederiks, B. J. M., Depla, M. F. I. A., Legemaate, J., Eefsting, J. A., \& Hertogh, C. M. P. M. (2011). The ideal application of surveillance technology in residential care for people with dementia. Journal of Medical Ethics, 37(5), 303-310. doi:10.1136/jme.2010.040774 PMID:21292695

Nordgren, A. (2012). The Web-Rhetoric of Companies Offering Home-Based Personal Health Monitoring. Health Care Analysis, 1-16. doi: doi:10.1007/ s10728-011-0174-z PMID:21553006

Nordgren, A. (2013). Personal health monitoring: Ethical considerations for stakeholders. Journal of Information. Communication and Ethics in Society, 11(3), 156-173. doi:10.1108/JICES-06-2013-0015

Page-Hanify, B. (1980). Intellectual Handicap - Achievement of Potential. Australian Occupational Therapy Journal, 27(2), 53-60. doi:10.1111/j.1440-1630.1980.tb01135.x
Palm, E. (2011). Who Cares? Moral Obligations in Formal and Informal Care Provision in the Light of ICT-Based Home Care. Health Care Analysis, 1-18. doi: doi:10.1007/s10728-011-0199-3 PMID:22179816

Palm, E., Nordgren, A., Verweij, M., \& Collste, G. (2012). Ethically sound technology? Guidelines for interactive ethical assessment of personal health monitoring. Studies in Health Technology and Informatics, 187, 105-114. PMID:23920461

Patterson, M. E., \& Williams, D. R. (2002). Collecting and analyzing qualitative data: Hermeneutic principles, methods and case examples. Champaign, IL: Sagamore Publishing, Inc.

Pentland, A., Lazer, D., Brewer, D., \& Heibeck, T. (2009). Using reality mining to improve public health and medicine. Studies in Health Technology and Informatics, 149, 93-102. PMID:19745474

Percival, J., \& Hanson, J. (2006). Big brother or brave new world? Telecare and its implications for older people's independence and social inclusion. Critical Social Policy, 26(4), 888-909. doi:10.1177/0261018306068480

PHMEthics Consortium. (2012). PHM-Ethics - Final Report (No. GA 230602). PHM Ethics Consortium. Retrieved from http://ethics.p-h-m.org/

Positive, I. D. (2011). PositiveID Corporation ${ }^{\mathrm{TM}}$ GlucoChip. Retrieved April 12, 2013, from http:// www.positiveidcorp.com/products_glucochip.html

Pousaz, L. (2013, March 13). Under the skin, a tiny laboratory. Retrieved April 12, 2013, from http:// actu.epfl.ch/news/under-the-skin-a-tiny-laboratory/

Puech, M. (2013). Ordinary Technoethics. International Journal of Technoethics, 4(2), 36-45. doi:10.4018/jte.2013070103

Remmers, H. (2010). Environments for ageing, assistive technology and self-determination: Ethical perspectives. Informatics for Health \& Social Care, 35(3-4), 200-210. doi:10.3109/17538157.2010.528 649 PMID:21133773

Rigby, M. (2007). Applying emergent ubiquitous technologies in health: The need to respond to new challenges of opportunity, expectation, and responsibility. International Journal of Medical Informatics, 76, S349-S352. doi:10.1016/j.ijmedinf.2007.03.002 PMID: 17434338 
Robinson, L., Hutchings, D., Corner, L., Finch, T., Hughes, J., Brittain, K., \& Bond, J. (2007). Balancing rights and risks: Conflicting perspectives in the management of wandering in dementia. Health Risk \& Society, 9(4), 389-406. doi:10.1080/13698570701612774

Sadri, F. (2011). Ambient Intelligence: A Survey. ACMComputing Surveys, 43, 36.1-36.66. doi:Article

Steele, R., Lo, A., Secombe, C., \& Wong, Y. K. (2009). Elderly persons' perception and acceptance of using wireless sensor networks to assist healthcare. International Journal of Medical Informatics, 78(12), 788-801. doi:10.1016/j.ijmedinf.2009.08.001 PMID:19717335

Stowe, S., \& Harding, S. (2010). Telecare, telehealth and telemedicine. European Geriatric Medicine, 1(3), 193-197. doi:10.1016/j.eurger.2010.04.002

Tiwari, P., Warren, J., Day, K. J., \& McDonald, B. (2010). Some non-technology implications for wider application of robots assisting older people. Health Care and Informatics Review Online, 14.

Topo, P. (2009). Technology Studies to Meet the Needs of People With Dementia and Their Caregivers A Literature Review. Journal of Applied Gerontology, 28(1), 5-37. doi:10.1177/0733464808324019

Townsend, D., Knoefel, F., \& Goubran, R. (2011). Privacy versus autonomy: A tradeoff model for smart home monitoring technologies. Proceedings of the Annual International Conference of the IEEE Engineering in Medicine and Biology Society, EMBS (pp.4749-4752). doi:10.1109/IEMBS.2011.6091176

Truong, Y., McColl, R., \& Kitchen, P. (2010). Practitioners' perceptions of advertising strategies for digital media. International Journal of Advertising, 29(5), 709-725. doi:10.2501/S0265048710201439

Ure, J., Pinnock, H., Hanley, J., Kidd, G., McCall Smith, E., \& Tarling, A. et al. (2012). Piloting telemonitoring in COPD: A mixed methods exploration of issues in design and implementation. Primary Care Respiratory Journal, 21(1), 57. doi:10.4104/ pcrj.2011.00065 PMID:21785816

van Hoof, J., Kort, H. S. M., Rutten, P. G. S., \& Duijnstee, M. S. H. (2011). Ageing-in-place with the use of ambient intelligence technology: Perspectives of older users. International Journal of Medical Informatics, 80(5), 310-331. doi:10.1016/j. ijmedinf.2011.02.010 PMID:21439898

van Hoof, J., Kort, H. S. M. D., Markopoulos, P., \& Soede, M. (2007). Ambient intelligence, ethics and privacy. Gerontechnology (Valkenswaard), 6(3). doi: doi:10.4017/gt.2007.06.03.005.00
Vuokko, R. (2008). Surveillance at Workplace and Home: Social issues in transforming care work with mobile technology. Journal of Information. Communication \& Ethics in Society, 6(1), 60-75. doi:10.1108/14779960810866800

Welsh, S., Hassiotis, A., O’Mahoney, G., \& Deahl, M. (2003). Big brother is watching you - The ethical implications of electronic surveillance measures in the elderly with dementia and in adults with learning difficulties. Aging \& Mental Health, 7(5), 372-375. doi:10.1080/1360786031000150658 PMID:12959806

Williams, A. (2002). Changing geographies of care: Employing the concept of therapeutic landscapes as a framework in examining home space. Social Science \& Medicine, 55(1), 141-154. doi:10.1016/ S0277-9536(01)00209-X PMID:12137183

Wu, Y., Fassert, C., \& Rigaud, A. S. (2012). Designing robots for the elderly: Appearance issue and beyond. Archives of Gerontology and Geriatrics, 54(1), 121-126. doi:10.1016/j.archger.2011.02.003 PMID:21349593

Ziefle, M., \& Rocker, C. (2010). Acceptance of pervasive healthcare systems: A comparison of different implementation concepts. Proceedings of the ICST Conference on Pervasive Computing Technologies for Healthcare (pp. 1-6). doi:10.4108/ICST.PERVASIVEHEALTH2010.8915

Zwijsen, S. A., Niemeijer, A. R., \& Hertogh, C. M. P. M. (2011). Ethics of using assistive technology in the care for community-dwelling elderly people: An overview of the literature. Aging \& Mental Health, 15(4), 419-427. doi:10.1080/13607863.2010.5436 62 PMID:21500008

\section{ENDNOTES}

The research reported here follows on from a literature review published in the proceedings of ETHICOMP 2011. See: Mittelstadt, Fairweather, McBride \& Shaw, 2011.

2 The amount of literature discussing privacy implications of PHM is too large to do this complex topic justice here, while giving sufficient treatment to other ethical aspects of PHM. An in-depth discussion of literature discussing privacy aspects of PHM can be found in Mittelstadt, Fairweather, McBride \& Shaw, 2013. 
Brent Mittelstadt is a Research Fellow in the Centre for Computing and Social Responsibility (CCSR) at De Monfort University. He is currently working on issues of ethics and emerging technologies, including governance and RRI. He holds two Master's degrees and has recently completed a PhD in Applied Ethics looking at social and ethical implications of personal health monitoring devices. He is currently contributing to the SATORI FP7 project by investigating good practice in evaluation of Mobilisation and Mutual Learning Action Plans. His immediate research interests lie in theories of discourse and virtue ethics, as well as the social and ethical implications of emerging ICTs and medical technologies, including how best to embed the principles of Responsible Research and Innovation into development and deployment.

Ben Fairweather is Senior Research Fellowin the Centre for Computing and Social Responsibility, and has been Editor of the Journal of Information, Communication and Ethics in Society since its first issue in 2003. His interests cover a wide range of the relationships between Morality, Social Responsibility and Ethics (on the one hand) and Technology, Computing and Research and Innovation (on the other hand). Of particular interest to Dr. Fairweather are Environmental aspects and Greening IT; aspects relating to Privacy, Disability and eGovernment (and especially eVoting); and questions of how to promote responsibility and virtuous behaviour in the fields of technology, research and innovation.

Mark Christopher Shaw is a Research Fellow in the Centre for Computing and Social Responsibility (CCSR) at De Montfort University, Leicester, UK. He qualified as a medical doctor (University of London, 1987) and specialized in Public Health Medicine (Member of the Faculty of Public Health, London, 2001) and changed careers, obtaining a second degree in computer science (Open University 2000). His main role in the CCSR is to develop research into health informatics and quality assurance. His is currently working on the Researcher Awareness Work Package of the Society and Ethics Sub-Project of the Human Brain Project. Please see http:// www.dmu.ac.uk/markshaw

Neil McBride is a Reader in the Centre for Computing and Social Responsibility at De Montfort University. He has a background in biological sciences including a PhD in molecular biology. He has over 20 years industrial and teaching experience in the ICT industry including product development experience with IBM and experience in Health ICT development. He has researched and written on information systems and IT service management. His current interests in the ethics of robotics and big data. He is currently working on the frameworks for RRI in robotics and a practical evaluation approach for PHM ethics. Dr. McBride's interdisciplinary background across social and ICT disciplines means he is well-placed to identify and understand the SSH issues faced in ICT development. 